\title{
The Role of Hierarchy, Example, and Language in Learning
}

\section{A Confrontation between a Liberal and a 'Critical' Understanding of Legal Education ${ }^{*}$}

Bart van Klink

\section{The use of knowledge}

In The Voice of Liberal Learning (a collection of essays published in 2001), Michael Oakeshott characterizes learning as a strictly non-instrumental activity. In schools and universities, knowledge is acquired for its own sake: 'learning here is not a limited undertaking in which what is learned is learned merely up to the point where it can be put to some extrinsic use; learning itself is the engagement and it has its own standards of achievement and excellence' (Oakeshott 2001, p. 11). Learning is an adventure: it does not follow a pre-established plan and has no final destination. According to Oakeshott (2001, p. 15), learning is liberal, because it has to be 'liberated from the distracting business of satisfying contingent wants'. Obviously, this liberal understanding of education differs fundamentally from a 'critical' notion of education as advocated by members of the CLS movement, among whom Duncan Kennedy. From a 'critical' perspective, Oakeshott's conception may be seen as yet another attempt - typical for liberalism and conservatism alike - to depoliticize the process of knowledge production and reproduction and to conceal (and thereby to strengthen and legitimize) its effects on the distribution of power, wealth, status and so forth in society.

Michael Oakeshott and Duncan Kennedy can be seen as exponents of two different strands in contemporary thinking about education, as described by Anthony T. Kronman (2007). Oakeshott belongs to the tradition of secular humanism that aims at initiating students in a 'great conversation' which shapes them intellectually as well as morally (Kronman 2007, p 86-87). Starting from the 1960s, this position came under attack because it was considered to be 'ideologically suspect' (Kronman 2007, p. 89). Knowledge was seen as power and it had to be used as an empowering tool for the powerless. In legal theory, Kennedy is one of the bestknown and most influential proponents of the second position. According to Kronman (2007, p. 90), the humanities are dominated nowadays by a 'culture of political correctness' which has contributed to their loss of influence and authority in the academic world.

* The author thanks the various colleagues who have commented on an earlier version of this paper, among whom Lyana Francot-Timmermans, Bald de Vries and members of the Department of Legal Theory and Legal History, VU University Amsterdam. Moreover, he is very grateful to Sanne Taekema for her last-minute language check. 
It is obvious that Oakeshott and Kennedy have developed their ideas in very different social, educational and historical contexts. Oakeshott introduced his notion of liberal learning in reaction to radical changes in the British educational system in the 1950s and 1960s. Kennedy, on the other hand, criticized (what he perceived as) the hierarchical and conservative character of legal education at US law schools, at least until 1983 when he published his well-known pamphlet 'Legal Education and the Reproduction of Hierarchy' (reprinted in Kennedy 2004b). In this article, I will move past the specific contexts in which these ideas have been developed and focus mainly on their more general significance for thinking about education, in particular legal education, at our contemporary law faculties in Europe. I intend to confront both views with each other, in order to elucidate the role that critical thinking plays or should play in legal education. What is the use of knowledge? Why do we as law teachers want students to develop a critical attitude? What does a critical attitude consist of and how can this be promoted?

First, I will clarify Oakeshott's notion of liberal learning (section 2). Second, I will show in which respects this understanding of education can be contrasted with and criticized from the viewpoint of critical legal education, mainly building on several writings of Duncan Kennedy (section 3). Third, I will attempt to refute this critique, in particular by arguing that it is based on false assumptions about the role that hierarchy, example (both in the sense of role modelling as in the sense of exemplifying) and language play in teaching (section 4). Finally, I will explore whether this critique could be used in order to strengthen the critical impetus of liberal learning (section 5). My general purpose is to develop a notion of skeptical legal education, which is to a large extent based on Oakeshott's understanding of liberal learning but which relativizes its insistence on the noninstrumentality of learning and reinforces its critical potential.

\section{The art of conversation ${ }^{1}$}

According to Oakeshott (2001, p. 10), the human world is essentially a 'place of learning.' As an animal rationale man is involved in an on-going process of attributing meaning to the world around him. By doing so, he creates a human world, not because this world solely consists of human beings and all the things that they produce, but primarily because it is a product of the human activity of signifying. Learning involves an unlimited semiosis: every attribution of meaning to the world by man is temporary and incomplete. Learning does not follow a preestablished plan and has no final destination. It is an adventure with an uncertain and unpredictable outcome: 'This engagement is an adventure in a precise sense. It has no preordained course to follow: with every thought and action a human being lets go a mooring and puts out to sea on a self-chosen but largely unforeseen course' (Oakeshott 2001, p. 11). 
Throughout his whole life man is engaged in learning. Within this education permanente schools and universities occupy a privileged position. Characteristic for these educational organizations is, to begin with, that those involved are recognized and recognize themselves as learners, besides possible other roles they may fulfill in society (such as musician, major or meter maid). Subsequently, learning in educational organizations is focused on the learning of something specific. It does not aim at promoting intellectual development, spiritual growth or the broadening of one's horizon in general, but at acquiring knowledge about a particular subject, within a particular discipline, with the help of the methods and conceptual tools typical for the discipline at hand. The learner has to conceive of learning as a specific task, which requires attention, patience and persistence. Although learning can in principle take place everywhere - for instance in a telephone conversation with a friend or during a stroll along the beach - in schools and universities it is carried out in a systematic way. Finally, in these organizations learning is not an instrumental activity, but a goal in itself. Knowledge is acquired not only, or not predominantly, for external purposes. Learning takes place in a separate sphere, far from our daily cares and concerns. Therefore, Oakeshott (2001, p. 15) characterizes learning as liberal, not in the political sense but in the existential sense of 'liberated' or 'freed': at least for a few years, learners do not have to worry too much about 'satisfying contingent wants'. What the university offers, is 'the gift of an interval' (Oakeshott 2001, p. 114).

Oakeshott (2001, p. 69) describes education as a transaction between generations which aims at introducing newcomers to an intellectual, imaginative, moral and emotional inheritance'. The inheritance is shaped and reshaped in an on-going conversation in which people are engaged in understanding themselves and their world. In order to be able to participate in this conversation, learners have to learn first to speak the language and to recognize the different voices that can be discerned within this language. Every academic discipline constitutes a language of its own, with its own rules, by means of which certain aspects of the world and human existence can be expressed. It is the task of the teacher to teach the students the rules of the language and to show how one can make one's own contribution to the on-going conversation. Liberal learning is an initiation in this art of conversation.

According to Oakeshott, the 'free' conversation that takes place at universities is threatened nowadays by various developments inside and outside the academic world. In ordinary life, he argues, mainly one language is spoken - the "language of appetite' (Oakeshott 2001, p. 33). ${ }^{2}$ It is a language full of clichés by means of which superficial impressions and emotions can be expressed in general terms that are recognizable and repeatable for everyone. ${ }^{3}$ Its sole purpose is to satisfy

2 Oakeshott is not very clear about what the 'language of appetite' exactly consists of. Below, I will give my own, somewhat loose interpretation of this notion.

3 This is reminiscent of the distinction that Merleau-Ponty draws between 'langage parlé' ('spoken' or worn-out language) and 'langage parlant' ('speaking' or innovative language). However, as Merleau-Ponty points out, this distinction is never absolute (cf. Corrias 2011, p. 63ff). 
immediate needs in the quickest, easiest and cheapest way possible. There is less and less room for reflection and meaningful experiences. The world is perceived as fully transparent and accessible; it does not contain any puzzles or mysteries anymore. Oakeshott points to two separate developments in particular. On the one hand, education becomes to a growing extent general education (Oakeshott 2001, p. 20-21). ${ }^{4}$ General education does not intend to teach something specific, but only to improve the student's intelligence or his/her capacity to think independently in general. Independent of any concrete context or question, intellectual faculties are trained, such as logical thinking, close reading or speaking successfully. On the other hand, learning is increasingly transformed into some form of applied education. That means that education is used for socializing students and preparing them for certain tasks in society. Instrumental learning replaces liberal learning and, as a consequence, teaching is reduced to the training of a series of technical functions (cf. Oakeshott 2001, p. 13). Education is directed at changing the student's attitude and behaviour: students have to learn how to deal with issues like sexuality, drugs and suicide (education as public information); by which norms or values they should live their lives (as in citizenship courses or courses of applied ethics); and how they can become more 'conscious' (as in consciousness raising courses) et cetera. ${ }^{5}$ Due to these developments, schools and universities are no longer free spaces of learning, where learners acquire knowledge mainly for its own sake.

Oakeshott (2001, p. 102) considers the growing attention that skills training receives in contemporary academic education as symptomatic for the second development, which leads to an instrumentalization of education. ${ }^{6}$ Increasingly, it is assumed that the main function of modern universities is to teach skills that require a special training. Oakeshott argues that education never coincides with the training of specific techniques, not even in vocational education. In order to know how to do something, one has to understand first what one is doing. In Oakeshott's view, knowledge contains two components: information and judgment. ${ }^{7}$ Information consists of both facts (for instance about what statutes are and where they can be found) and rules that prescribe how a specific skill (such as the interpretation of a certain statute) has to be carried out. Judgment is the

4 In the essay 'Education: The Engagement and Its Frustration', Oakeshott (2001, p. 73-78) discusses a similar development in which education is centred around the self-development of children. Teachers are no longer engaged in conferring a certain understanding of the world, but in promoting the children's freedom and creativity. In Oakeshott's view, this activity cannot properly be considered to be teaching: 'Teaching is to be confined to hesitant (preferably wordless) suggestion; mechanical devices are to be preferred to teachers, who are recognized not as custodians of a deliberate procedure of initiation but as mute presences, as interior decorators who arrange furnishings of an environment and as mechanics to attend to the audio-visual apparatus' (Oakeshott 2001, p. 75).

5 These examples are taken from Fuller (2001, p. xvii).

6 For a critique on Oakeshott's depreciatory view on the role of skills training in education, see Van Klink (2011, p. 222-225).

7 For clarity's sake I have simplified Oakeshott's rather detailed and complex view on knowledge that he has expounded in the essay 'Learning and Teaching' (Oakeshott 2001, p. 35-61). 
knowledge that makes it possible to interpret information and to assess its relevance and, moreover, to determine which rule has to be applied in a given case and which actions are required by this rule. Without knowledge of this kind one would not be able to learn a skill: 'Before any concrete skill or ability can appear, information must be partnered by "judgment," "knowing how" must be added to the "knowing what" of information' (Oakeshott 2001, p. 49). A lawyer, for instance, needs to know more than the content of the legal norms; s/he must also know which norm s/he has to apply in a given case and how that norm has to be interpreted in the case at hand. This kind of knowledge cannot be expressed in rules or, in other words, be translated into information. It gives us guidance in situations where there are no specific rules or methods available or where we do not know which rule or method to apply. Generally speaking, when we learn a language - whether it is English or Spanish or the language of philosophy or the law's language - it does not suffice to learn the rules only. A competent speaker is someone who is able to express himself or herself in a way that is not prescribed explicitly by the rules. Judgment cannot be taught, because it cannot be made an independent object of study. The teacher transmits it implicitly when giving information: 'It is implanted unobtrusively in the manner in which information is conveyed, in a tone of voice, in the gesture which accompanies instruction, in aside and oblique utterances, and by example' (Oakeshott 2001, p. 60). Students develop their judgment by recognizing and appreciating the individual intelligence at work in the way in which the teacher thinks and speaks, in his or her personal style and mode of expression.

In the past, nobody gave lessons in the art of conversation, but it had to be learnt by listening to competent speakers engaged in conversation. According to Oakeshott (2001, p. 147), 'only a Sophist would have considered the art of conversation to be a separate techne'. Education is not about learning techniques in order to achieve a certain goal; to know oneself - following the old Greek adage gnothi seauton ( $\gamma v \tilde{\omega} \theta \imath$ $\sigma \varepsilon \alpha v \tau o ́ v)$ - is an end in itself. Knowledge requires a long and intensive learning process in which one gradually gets acquainted with the art of conversation. There are no shortcuts for learning by way of simple techniques or 'easy methods' (Oakeshott 2001, p. 179). Only by 'submerging' oneself in the practice of scholarship one can become a full-fledged participant in this practice.

\section{The battle ground of legal education}

\subsection{Training for subservience}

A completely different picture of learning emerges, when one studies the writings of Duncan Kennedy on legal education. Kennedy (1986, p. 603) considers legal education to be 'a battle ground between conservative and more left approaches'. In his view, legal education - as it is practiced at US law schools by conservative and liberal teachers - consists of 'ideological training for willing service in the hierarchies of the corporate welfare state' (Kennedy 2004b, p. 15). At the core of this ideology is the conviction that law can be distinguished from policy. The legal 
system is presented as a neutral institution, separated or separable from politics and ethics. Cases that justify the basic rules and ideas prevailing in a certain field of law are treated as 'cursory exercises in legal logic' (Kennedy 2004b, p. 34). Students who question the outcome of a certain case, are accused of being 'naïve, nonlegal, irrelevant' because they mix up legal and policy considerations (Kennedy 2004b, p. 23). They simply fail to master the legal technique that is required to understand the law. Likewise, cases that are outdated or decided wrongly (the anomalous cases) are criticized as errors in legal reasoning. Thus, legal reasoning does not only serve to legitimize the law, but can also be used as an analytical, allegedly objective tool for criticizing the law. In the margin, the supposedly few 'cutting edge' cases that raise policy questions are discussed in a rather freewheeling fashion. Kennedy argues that legal education in the US has a threefold structure. In the first year, students learn the basic rules of contracts, torts, property, criminal law and civil procedure that constitute 'the ground-rules of late nineteenth century laissez-faire capitalism' (Kennedy 2004b, p. 35). Subsequently, the courses offered in the second and third year expound 'the moderate reformist program of the New Deal' (Kennedy 2004b). Finally, there are the 'peripheral' courses, such as legal philosophy and legal history, which are presented as 'not truly relevant to the "hard", objective, serious, rigorous, analytic core of law; they are a kind of playground or a finishing school for learning the social art of self-presentation as a lawyer' (Kennedy 2004b, p. 36).

For students, legal education is basically a pacifying and passivizing experience. Many of them came to law school with progressive ideals to make the world more just. In the course of the curriculum students are passivized in two respects: in the classroom they are, first, discouraged to discuss cases on a policy level and to question the ethical and political values involved; and, second, they are encouraged to accept the legitimacy of the existing legal system. Kennedy does not deny that students do learn some useful analytical and argumentative skills, but in general legal education only serves to produce 'ideological legitimation for the system of hierarchy' (Kennedy 1986, p. 605). In law schools, dominated by mainstream liberal and conservative teachers, 'a set of political attitudes towards the economy and society in general, toward law, and toward the possibilities of life in the profession' is imparted, together with 'a complicated set of institutional practices that orient students to willing participation in the specialized hierarchical roles of lawyers' (Kennedy 2004b, p. 30). The system of hierarchy is reproduced in various ways. Kennedy argues that hierarchies within the law school (and also between law schools) function as a model for the hierarchies in the world outside academia, that is, in law firms, companies, courts and so on. According to him, law teachers act as role models for students by showing them how to speak, think, look, act and, in particular, how to treat people lower in rank, such as secretaries and students. Just like Oakeshott (but, of course, for completely different purposes), Kennedy (Kennedy 2004b, p. 59) compares education to the learning of a language - a language which enables the young lawyer 'to convey that she knows what the rules of the game are and intends to play them'. Again like Oakeshott (and once more for different reasons), Kennedy stresses the importance of 
style in teaching. In very little things - 'mannerisms, ways of speaking, gestures' 'the white, middle-class cultural style' is transmitted, even by some black and female teachers:

Teachers are overwhelmingly white, male, and middle class, and most (by no means all) black and woman law teachers give the impression of thorough assimilation to that style, or of insecurity and unhappiness. (...) The teacher sets the tone - a white, male, middle-class tone. Students adapt. (Kennedy 2004b, p. 78)

What is needed, in Kennedy's view, is nothing less than the 'total dismantling of the system' (Kennedy 2004b, p. 121). American society should be transformed radically, which requires the 'building of a left bourgeois intelligentsia that might one day join with a mass movement' (Kennedy 2004b, p. 117). As part of this broader program of radical change and resistance, a 'law school struggle' has to be set up (Kennedy 2004b, p. 119). The law school should be reformed drastically and turned into 'a counterhegemonic enclave' (Kennedy 2004b, p. 137). For that purpose, Kennedy (1994, p. 86-88) proposes a threefold strategy. ${ }^{8}$ First, the small group of radical students should be encouraged and supported by left-wing teachers to build 'a coalition of anybody who wants to shake up the status quo' (Kennedy 1994, p. 86) or a 'minoritarian alliance' (Kennedy 2004c, p. 215). Outside the classroom, a 'left study group' has to be established (Kennedy 2004b, p. 125). Kennedy (2004c, p. 215) has no illusion that by building study groups alone the system can be abolished, but his aim is to find 'some way to rebel in law school'. Second, liberal students - from whom the radicals should differentiate themselves sharply - must be persuaded to move to the left. By engaging them in an 'ideological conversation' (Kennedy 1994, p. 87), they have to learn that liberal views are not simply an expression of what moral people think or should think but, like every political position, ideological commitments. Moreover, they have to be confronted with 'the limits of moderation' (Kennedy 1994). The final objective is to make conservative students, who have become more and more confident during the last years, less secure and self-righteous. In his own teaching, Kennedy has used different cases for different groups of opponents. In order to 'politicize the classroom' cases have to be selected that are controversial within the group at hand and that, therefore, will cause the group to split in two: liberal students have to study cases in which the court has ruled in an extremely liberal way, whereas conservative students are exposed to an extremely conservative court decision. In Kennedy's view, it is not the teacher's role to impose his/her political views on students, but to make them aware of the injustice of the current legal system and to show them how they as lawyers sustain the system and, more importantly, how they can subvert it. 


\subsection{Right-wing teaching}

From Kennedy's 'critical' perspective, ${ }^{9}$ Oakeshott's notion of liberal learning will undoubtedly appear as highly uncritical and conservative. To conceive of science as the quest for knowledge for its own sake is to disguise the political nature of knowledge production and transfer and their effects on the hierarchical structure of society. Kennedy does not deny that science is about discovering the truth but that truth will inevitably be, at least in the study of law, a political truth that is determined by the subjective political views of the scholar: '(...) if you are serious about the proposition that law is political, then you have to accept that views of law will be different according to the political vision of the person who holds them. So your truth about law, whatever it is, will be a partial truth, rather than an absolute one; it will be a political truth' (Kennedy 1986, p. 608). Whereas Oakeshott's liberal learning is directed first and foremost at understanding the world, Kennedy would argue - following Marx - that the point is not merely to understand the world but to change it. The 'interim' the university offers, is not an escape from reality in order to reflect on it from some detached, apolitical and care-free position but, in Kennedy's view, it prepares the student for later political interventions in reality by giving him/her the opportunity to experiment with resistance:

'If you want a long-term life project that works against loss and injury and oppression, going to law school is a way to find out. (...) The drawback of this strategy is that it means treating three years of your life as a mere interim. Focusing forward to a job and inward to family and sideways to a nonacademic community, however defined, means passing up the chance to experiment with resistance to the system while you are still relatively autonomous within it. (Kennedy 2004a, p. 6-7)

Education in Oakeshott's conception threatens to become a very pacifying and passivizing experience which, according to Kennedy, defines mainstream education in law schools in general. Liberal learning does not aim at engaging students in political debates or 'ideological conversations', but at initiating them in the art of conversation characteristic for a certain discipline. The teacher acts as a role model by demonstrating students how they have to speak and think within that discipline. By merely listening and getting acquainted with the teacher's mode of expression, students are expected to develop their faculty of judgment. They have to master the language first, before they are allowed to speak for themselves. Kennedy would surely dismiss this kind of role modelling as 'teaching by example' by which hierarchical relations outside the academic world are reproduced: the teacher/student relationship functions as 'the model for relations between junior associates and senior partners, and also for the relationship between lawyers and

9 I have used inverted commas in order to indicate that it concerns a very specific, political understanding of criticism (informed by Neo-Marxist, postmodern political theory), which by no means excludes other ways of being critical, as I will argue in the next sections. 
judges' (Kennedy 2004a, p. 77). The teacher does set the tone but, in most cases, it will be 'a white, male, middle-class tone' (Kennedy 2004b, p. 78).

More importantly, it may be argued that liberal learning - however 'liberated from the distracting business of satisfying contingent wants' (Oakeshott 2001, p. 15) - in fact serves to promote a conservative political view which encourages students to accept the world as it is. Or, in any case, students are certainly not encouraged to use the knowledge and skills that they have acquired at the university to subvert power relations in society. In Oakeshott's view, understanding is an end in itself and students learn nothing about the way in which this understanding can be put to some extrinsic use. Although Oakeshott does not promote a conservative educational program actively (nor does he present himself explicitly as a conservative ${ }^{10}$ ), his view on education might be qualified, in terms of Kennedy (1986, p. 608), as 'right-wing teaching' for three reasons: (1) he considers learning to be primarily a non-instrumental activity separated from other social practices; (2) he ignores completely the political nature of knowledge; and (3) the teaching model he offers is utterly hierarchical and unidirectional.

Oakeshott's latent conservative agenda can be made more manifest by taking into account his political philosophy (see, for instance, Oakeshott 1975 and 1991). From a 'critical' stance, it will be apparent that Oakeshott - under the disguise of his seemingly neutral positivist understanding of law ${ }^{11}$ - actually advocates a limited government that aims at keeping public interventions in private activities of citizens to a minimum. Moreover, in terms of empowerment, Oakeshott's political philosophy does not have very much to offer. On the contrary, instead of activating citizens, his skepticism towards the possibilities of human intervention will probably have a paralyzing effect on people. In a famous analogy, Oakeshott (1991a, p. 60) compares politics to sailing:

'In political activity (...) men sail a boundless and bottomless sea; there is neither harbour for shelter nor floor for anchorage, neither starting-place nor appointed destination. The enterprise is to keep afloat on an even keel; the sea is both friend and enemy; and the seamanship consists in using the resources of a traditional manner of behaviour in order to make a friend of every hostile occasion.'

Because we do not know where we came from and where we are going to, the best thing to do - in Oakeshott's view - is 'to keep on keeping on' in the way we are used to. This is the deathblow to every kind of radical left-wing politics which aims at liberating people from oppressive traditions. The current economic structures have caused severe and possibly irreparable damage to the environment and

10 Generally, Oakeshott is considered to be a conservative philosopher, although he seems to move to a more libertarian position in his later work (see Franco 1990, p 7-12). For Oakeshott's view on the conservative disposition in politics, see in particular Oakeshott (1991b).

11 For a comparison between Oakeshott's and Kelsen's conception of law and the Rule of Law, see Van Klink \& Lembcke (forthcoming). 
have led to great inequality and injustice in the relations between people. Therefore, as Kennedy would argue, 'the system' has to be abolished completely. The status quo must be shaken up, to begin with by politicizing the classroom.

\section{A critique of 'critical' legal education}

In an imaginary encounter with Kennedy's view on 'critical' education, I have construed a fundamental critique of Oakeshott's notion of liberal learning. Following Kennedy, Oakeshott can be accused of passivizing students and preparing them for 'willing service in the hierarchies of the corporate welfare state'. How should this critique be addressed? In an attempt to respond to the several points of criticism raised in the previous section, I will focus in particular on the different roles that both authors assign to hierarchy, example (both in the sense of role modelling as in the sense of exemplifying) and language in teaching. In addition, I will discuss their divergent views on the relationship between theory (or science) and practice (or political activity) which lies at the root of their conflicting conceptions of education. By confronting a 'liberal' and a 'critical' notion of learning, I intend to indicate which of the 'critical' criticisms, in my view, are justified and can be used to develop a more critical (or more explicitly critical) version of liberal learning, which I will present in the final section.

To begin with, in Kennedy's writings the concept of hierarchy is used mostly in a negative sense. ${ }^{12}$ As a self-acclaimed 'extreme leftist' (Kennedy 1994, p. 83) with anarchist and Marxist sympathies, Kennedy considers hierarchy to be a bad thing, generally speaking, because it produces and reproduces unjustified inequalities and relations of exploitation between people. In his view, legal education paves the way for hierarchies in legal practice: 'Legal education at present is a not insignificant producer of ideological legitimation for the system of hierarchy' (Kennedy 1986, p. 605). US law schools are able to function as a 'reproducer of hierarchy' (Kennedy 1986, p. 605) through the use of various techniques, among which the grading system and the ranking system. In the current grading system grades are distributed to students at the end of every course on the basis of disputable criteria. Thereby, legal education creates and sustains arbitrary, unjustifiable differences among students. The ranking system operates in a similar way, but then in the relationship between law schools. ${ }^{13}$ Kennedy does not seem to reject assessment as such, but he considers the grading system as employed in law schools nowadays to be inappropriate for three reasons in particular. First, the system is not connected to what students deem to be a fair grading. Students experience the grading in general to be 'almost totally arbitrary', because it is

12 Kennedy (2004b, p. 97) does acknowledge that some hierarchies are 'OK' (for instance, in a parent-child relationship), but pays no attention whatsoever to the question how 'the right sort of hierarchy' might be reproduced (I have borrowed this felicitous phrase from Carrington 2004). Predominantly, he conceives of hierarchy as a constraint from which one has to be liberated (see, e.g., Kennedy 2004b, p. 112-113).

13 Since Kennedy only refers to it occasionally, I will not elaborate on it here. 
'unrelated to how much you worked, how much you liked the subject, how much you understood going into the exam, and what you thought about the class and the teacher' (Kennedy 2004b, p. 43). Second, by grading them periodically, a rank ordering among students is established and fixed as a 'natural order' that students simply have to accept. Hierarchy is presented as something that is inevitable and just, whereas Kennedy considers it to be false and unnecessary: it is false because the differences that are created by the grading could be diminished if students would receive more feedback while the course is still running; and it is unnecessary since differentiation is not needed for the proper functioning of legal practice: 'Most of the process of differentiating students into bad, better and good could simply be dispended with without the slightest detriment to the quality of legal services.' (Kennedy 2004b, p. 43) Following Kennedy's general critique on legal education, it can finally be argued that exams are based on the ideologically suspect distinction between law and policy. The assignments presuppose that one right 'legal' answer or 'the "correct solution" can be found in every case (Kennedy 2004b, p. 42), irrespectively of subjective ethical and political preferences, which is an illusion.

Without denying that hierarchical relations can be unjustified and oppressive, I believe that hierarchy is something we cannot do without, either in education or in society at large. In different stages of their academic career, students are confronted with grading. At the beginning, they are granted access to the university if they meet the requirements of prior education. Not everyone is allowed to enter: one has to prove first that one is capable of learning on a basic academic level, before one is admitted to the 'community of learners' ${ }^{14}$ Some sort of preselection is required in order to preserve the university as a place of learning in Oakeshott's sense. Without this initial distinction between people who are susceptible to learning and those who are not or less so, the university could not exist. Of course, this distinction is hierarchical because it favours students over other people by giving them the opportunity to learn (and thereby presumably to acquire a more interesting and better paid job afterwards). However, this initial distinction is justifiable because it serves to protect the central institutional value of the university, which concerns the accumulation and transmission of knowledge. After their admission, students will receive a grade for every course they have participated in after having taken an exam or written a paper. The student's achievements will be assessed according to professional standards generally accepted in law school. Obviously, these standards may be debatable (as much as their application to concrete cases), for instance when they are based on an untenable distinction between legal and policy considerations. If so, the stan-

14 This concept plays a central role in the learning conception of VU University Amsterdam, to which I am affiliated. In a policy document, entitled Handboek Onderwijskwaliteit (Manual Educational Quality, 2011; available only in Dutch at <www.vu.nl〉), it is explained as follows: 'The educational view of VU University Amsterdam can be summarized in one sentence: the university is a community of learners that pays attention to the ambition and talent of the individual student' (p. 9, my translation). I use this concept in the more general Oakeshottian sense of a community of people who participate in the activity of learning. 
dards have to be debated within the community of teachers that is responsible for the determination and application of standards for assessing the student's achievement. The standards only concern his/her achievement in terms of learning and, therefore, only address the question whether the student has learned sufficiently - that is, whether s/he has acquired the knowledge and skills required for the course - or not. For the assessment it is completely irrelevant how much effort the student has put in his/her work, whether s/he liked the subject, the class or the teacher, and how well prepared s/he was for the exam - it is solely the achievement itself as a learning achievement that matters. If students are not satisfied with their grading they have, of course, the right to ask for clarification or to complain. In the end, however, it is the teacher who determines the assessment. Assuming that it is based on adequate (accepted and acceptable) standards and an adequate application of these standards, the assessment will tell students to what extent they have met the standards required for the course and in which respects they could or should improve. Ideally, the final exam is not the only occasion when the students receive feedback on their learning progress, which should also be given at different moments during the course. ${ }^{15}$ The hierarchy that grading creates among students is not fixed: a bad grade will stimulate students to perform better next time. After students have graduated, their grades will play an important (though not necessarily decisive) role in finding a job. Employers will take grades as one indication among others - for instance, social skills and presentation - for assessing whether applicants are suited for the job. However, grading is primarily an instrument to assess the student's learning achievement with respect to the standards required for the course at hand. It is not a tool for selecting people, although it is often used as such. Therefore it is not relevant, as Kennedy puts forward, that the differentiation that grading creates between bad, better and good students is not useful for legal practice. If carried out properly, assessments culminating in grades are useful for students because they learn how to improve their learning.

Subsequently, Kennedy is highly critical about 'teaching by example' which, in his view, also serves - next to grading and ranking - to produce and reproduce hierarchy in legal education. In their interactions with students and secretaries, law teachers offer models of behaviour that are transferred to relations in law firms, for instance between senior partners and junior associates. There are several ways to respond to this criticism. First, it can be asked what exactly these 'models of behaviour' consist of. I presume that Kennedy refers to the formal and authoritarian manner in which law professors approached people lower in rank at least in the past. It is my impression, based on my limited experience of law schools in Europe, that relationships in universities are becoming more and more informal and less (or less overtly) authoritarian. So it seems to me that if there is one model of behaviour that nowadays informs hierarchical relations in universities 
and elsewhere it is predominantly the communicative and responsive model. ${ }^{16}$ Second, if we assume that some (overtly or disguised) authoritarian models of behaviour still prevail in law schools, it may be questioned whether students will adopt them uncritically. Kennedy (2004b, p. 62) posits an 'analogy effect' between legal education and legal practice: the models of behaviour that law teachers offer will make the relationships on the shop floor seem natural - like "'the way things are"' (p. 63). He even claims that through role-modelling "legal education contributes causally to hierarchies of the bar' (2004b, p. 74). Students learn from teachers 'how they are supposed to think, feel and act' (2004b, p. 74). In my view, this overestimates the influence teachers can exert on students and underestimates the ability and critical agency of students to act and think for themselves. ${ }^{17}$ In our age of modernity people seem in general to be less inclined to accept traditional authority and hierarchy. ${ }^{18}$ Third, I would claim that some kind of hierarchy and authority is a necessary condition for learning. As I have argued above, the hierarchy created by the grading system encourages students to perform better, both in comparison to their earlier achievements and to the achievements of other students. Moreover, the only way to learn something from someone else is to accept his/her authority on certain topics. That is, students have to recognize the teacher as an expert who possesses knowledge and skills in a specific area that they do not have themselves (or to a lesser extent). By accepting his/her authority, students become receptive to the lessons the teacher wants to convey. Kennedy does not deny that he, as a teacher, represents some sort of authority vis-à-vis his students. But, as he stresses, that does not by necessity mean that he indoctrinates them: ${ }^{19}$

'I think I can politicize my classroom without being guilty of indoctrination in the sense of transmitting my set of prescriptions for good law on the basis of my authority as a teacher. The idea is to politicize the classroom around the students' political views. (...) I'm imposing on them that it's very hard to escape the politics of law. (...) As long as I do not indoctrinate or preach about what the rules should be, I don't think I can really avoid a professional obligation to teach them that law is politics, because that's what I think it is.' (Kennedy 1994, p. 84-85)

Kennedy blames law teachers for indoctrinating students with a certain way of thinking and speaking. But, as Oakeshott argues, learning by necessity involves

17 So I don't agree with Kennedy's claim that 'most students believe what they are told' (Kennedy 2004b, p. 16). Shain (2000, p. 8-9) makes a similar point.

18 Weber (1994, p. 311-312) offers a classical analysis of this development.

19 In an earlier article, Kennedy does admit that he uses indoctrination in liberal thought as a counter strategy against conservative students. However, he considers it to be justifiable: 'There is a sense in which this is a form of indoctrination. That doesn't bother me; it's indoctrination in a mode of liberal argument within law, and let's face it, it's as useful - professionally useful - to conservative students as to anyone else. There are a lot of liberal judges out there' (Kennedy 1986, p. 615). 
the transfer of a vocabulary and a mode of thinking specific to a certain discipline. Only by learning this language, the student will be able to master the discipline. Obviously, Kennedy is afraid that students, while learning a language, are drilled in an ideologically suspect, liberal or conservative mode of legal thinking which conceives of legal reasoning as a neutral, value-free activity. ${ }^{20}$ In every learning process, however, values are transmitted. As Oakeshott argues, education is a transaction between generations which aims at introducing newcomers to an 'intellectual, imaginative, moral and emotional inheritance' (Oakeshott 2001, p. 69). In legal education, a central part of this inheritance consists of the bulk of legal norms that can be found in, for instance, treaties, statutes and court's decisions and that are described and discussed by legal scholars. Law students have to be made acquainted with the legal doctrine, not in order to be indoctrinated but to learn what the law is according to some authoritative understanding of it. Kennedy is surely right that every interpretation of the law involves values - not only legal but moral and political values as well. Law teachers should not disguise the values at stake, but make them explicit. As I will argue in more detail below, that does not mean that teachers should deliberately promote a conservative, liberal, radical left or any other political position. The classroom is no place for political activism. Students have to learn how the law is commonly understood and evaluated within the community of law teachers and be granted the freedom to develop their own opinion on the law's meaning and value. For that purpose, it is important that cases are selected, not in order to start a political discussion as Kennedy proposes, but to demonstrate what (according to some authoritative understanding) the main lines of development in law are in a certain area, at a certain moment in time. In other words, the examples chosen have to fit the doctrine, not some political program.

I agree, however, with Kennedy that legal education still is, generally speaking, a passivizing experience. In particular in the first years, due the large number of law students, many lectures are offered to large groups. While the teacher is speaking, the students have to sit and listen and, if they are lucky, they may raise a question every now and then. Oakeshott's conception of liberal learning does not offer many clues for activating students. In his view, education is mainly a one-way communication: the teacher transmits information to students and helps to develop their faculty of judgment, both by giving a good example (in the sense of role modelling) and by giving good examples (in the sense of exemplifying). As explained above, he conceives of knowledge as a synthesis of information and judgment. Both elements cannot be acquired separately, on different moments or in different classes. They are learnt at the same time, though in different ways. According to Oakeshott, the transmission of information takes place through instructing, whereas the faculty of judgment is developed by imparting, that is teaching by example. ${ }^{21}$ E.g., the skill of law application cannot be trained

20 Kennedy (2004b, p. 99) speaks disapprovingly of 'the conceptual, scientific, social theoretical, aesthetic-modernist language of the world bourgeoisie'.

21 The distinction between 'instructing' en 'imparting' is explained in Oakeshott (2001, p. 54). Oakeshott (2001, p. 60-61) discusses 'teaching by example'. 
as a separate technique, but only in connection to the development of judgment, so that law students learn that jurisprudence requires both factual knowledge about the content of the law (ius) and practical wisdom (prudentia). ${ }^{22}$ So, in Oakeshott's view, students are initiated in the art of conversation basically by listening passively to the lectures of proficient teachers. There seems to be no room whatsoever for student's participation in the course. This is in line with Aristotle's recommendation that, in order to acquire prudence, one has to 'pay attention to the undemonstrated assertions and opinions of experienced and older people, or of the prudent, no less than to demonstrations, for they have an experienced eye, they see correctly' (Aristotle 2011, p. 130). I do not deny the importance of learning from more experienced and prudent people in education. On the contrary, for that reason I have argued earlier that authority and hierarchy cannot be dispended with in education and criticized Kennedy for neglecting this crucial aspect of learning. However, if learning is aimed ultimately at creating one's own voice or mode of expression, then it is important that students also participate actively in the course, for instance in group discussions and presentations. In order to master the language of a given discipline, students should regularly be given the opportunity to speak themselves. By receiving critical and constructive feedback from fellow students and the teacher, they will gradually become competent speakers.

The conflicting views that Oakeshott and Kennedy have on the role of hierarchy, example and language in learning can to a large extent be traced back to their fundamentally different opinions on the nature and the use of knowledge. According to Oakeshott, as we have seen, understanding the world and the human condition is primarily a goal in itself. He would, of course, not deny that academic research and education can and will have all kinds of (social, political, psychological and other) effects in the world outside the university, but these are - in this line of thinking - by-products in the essentially non-instrumental quest for knowledge. Kennedy, on the contrary, considers knowledge to be a practical and political tool which is either used to sustain the status quo (by mainstream law teachers) or to subvert it (by radical left-wing teachers like Kennedy). In his view, denying the political nature of knowledge production and transfer is part and parcel of a political (liberal or conservative) strategy to reproduce the existing power relations. This is a very fundamental issue that cannot be solved easily in an exchange of arguments. It is deeply rooted in one's personal opinion about what the university is for and how knowledge should be made useful for society. Therefore, I can give my own reasons for defending a liberal notion of learning, but I have no illusion that I will ever succeed in convincing anyone who conceives of truth as political truth and knowledge as a political instrument. Vice versa, those who adhere to a liberal notion, like myself, will consider Kennedy's conception of 'critical' legal education to be symptomatic for the contemporary instrumentalization of learn- 
ing. As Oakeshott argued (see section 2), learning is increasingly transformed into some form of applied education which aims at socializing students and preparing them for certain tasks in society. In Kennedy's view, the interim that the university offers should be used to raise awareness about the political nature of law and to encourage students to rebel in and outside the university. For Oakeshott, on the other hand, it is a temporary suspension from our daily worries which gives us time to think. What troubles me in Kennedy's notion of 'critical' legal education is that he reduces knowledge - and, in particular, knowledge of the law - to politics. In his conception, education is politics with other means. By politicizing the classroom, Kennedy turns the university into a preparatory school for subversive activities. There is nothing wrong with political activism as such (as long as it remains within the limits set by the law), but the university is not the right place to promote it. As Max Weber (1989, p. 19) has put it, 'politics has no place in the lecture-room'. Kennedy has no regard for the special character of the university as a place of learning. The university constitutes a relatively autonomous sphere in society where knowledge is produced and transmitted without a direct concern for its practical use. Of course, the various ways in which knowledge affects society - for the good as well as for the bad - should be studied, not so much in order to intervene in society immediately but primarily for the sake of understanding. Therefore, I do consider it valuable to study law from a political point of view, but it should not be the only perspective from which the law is studied. ${ }^{23}$ In legal education (in contrast to, for instance, political education) the main focus has to be a legal one: what the law is and ought to be according to the community of law teachers.

What is entirely lacking in Kennedy's conception of 'critical' legal education, is a feeling for the fragility of knowledge, its uncertainty and open-endedness. Scientific knowledge does not offer blue-prints for amending society and, if so, one has every reason to distrust it deeply. If carried out in a proper way, academic education prepares students not to embrace any kind of political ideology (either of a conservative or a progressive strand), but instead to question it and to debunk it. It is not the teacher's task to impose his/her worldview on students. A teacher should resist the temptation of becoming a preacher for a specific political or social cause, however noble or desirable. As Weber (1989, p. 20) argues, 'the true teacher will guard against imposing any attitude on the student from the lectern whether explicitly or through suggestion'. Science can provide the 'man of action' with clarity, so he can make his own choice among the competing worldviews (Weber 1989, p. 25). So I do believe, with Kennedy, that education should be critical. However, in my view, 'critical' does not mean understanding society according to some pre-established political scheme which divides it neatly into three groups of people: the bad ones (that is, the conservatives), the good ones (the radical lefties) and those who should know better (the moderate, mainstream liberals). This different sense of being critical I intend to capture in my notion of skeptical legal education. 


\section{Skeptical legal education}

Education should be critical, that is, it should be aimed at promoting critical thinking by students and developing their faculty of judgment. Students have to learn to make their own assessment of the information that they receive from teachers while reading literature and listening to lectures. To make one's own assessment does not mean that one has to invent the standards of evaluation from nowhere, but that one builds hermeneutically and critically on the values that are already accepted within the community of legal scholars. Whereas Carrington (2004, p. 149) conceives of 'moral and intellectual autonomy' as the ultimate goal of education, I would prefer to speak of the moral and intellectual integrity to use one's 'own' faculty of judgment. The student's autonomy is always related and relative to the intellectual environment in which s/he is raised. For the development of judgment in the context of legal education in particular three conditions have to be met. These conditions which I will discuss briefly below concern the student's activity in and outside the classroom, the manner in which the teacher transfers knowledge and the institutional context respectively. Taken together, they make up my conception of skeptical legal education. I have derived them to a large extent from Oakeshott's notion of liberal learning as described above, but I have added some elements from Kennedy's conception of 'critical' legal education in order to make the learning process more (or more explicitly) critical, more engaging and less 'inward oriented'.

To begin with, legal education should give more room for student participation in courses. According to Oakeshott, students have to learn the language of a specific discipline, so that one day they are able to generate new utterances in this language. For that purpose it is essential, as I have argued above, that students participate more actively in class than Oakeshott acknowledges. One may learn a lot from listening to competent speakers, but in order to master a language fully, one must regularly be given the opportunity to speak for oneself. This may be accomplished by means of group discussions, presentations, moot courts and so, and solely in classes of limited size. The cases discussed in law courses should give a representative overview of the law as it is (according to some authoritative interpretation), not in order to politicize the classroom as in Kennedy's conception, but to make students understand the law in its present state so they can make their own assessment of it. Moreover, students should be encouraged to discuss topics also outside the classroom, for instance, in internet forums.

What is required, furthermore, is that law teachers convey information from a detached point of view. That is, they should present the law as it is (according to their interpretation) as much as possible independently from their own ethical and political preferences. ${ }^{24}$ If they evaluate the current law and give recommendations to amend it, they have to make clear that they are not describing the law

24 This requires what Raz (1979, p. 158) calls 'non-committed detached statements': 'Since one may know what the law is without knowing if it is justified, there must be a possibility of making legal statements not involving commitment to its justification.' 
as it is at a certain moment in time but are expressing their personal opinion about how the law ought to be in the future. Value judgments are controversial in science, because their validity depends on the acceptance of certain values and ultimately of a worldview (or an ideology in 'critical' terms) whose truth can never be established by scientific means. ${ }^{25}$ So when teachers are evaluating the law, they should make clear on the basis of which values they are reasoning, how they understand these values in the given situation, and how their evaluation is connected to their general worldview. Or they can, as Weber (1989, p. 25-26) suggests, offer examples of hypothetical reasoning: if one accepts a specific value (for instance, democracy), one has to acknowledge certain rights as well (such as the freedom of speech), without committing themselves (nor the students) to the acceptance of this value. By doing so, they give students the opportunity to arrive at a different assessment, building on different values, on a different understanding of the same values, or on a different worldview. Similarly, they should explain and justify on the basis of what theoretical assumptions and what sources they make factual assertions about the content of the law.

Knowledge is always fallible and disputable, both when it comes to normative and factual statements. In order to give students a sense of the fragility of knowledge, it is important that teachers in group discussions with students take a counter position against the communis opinio in the group at hand, question it and demonstrate its ultimate groundlessness, as in Socratic dialogues. ${ }^{26}$ Inspired by Socrates, ancient Greek sceptics such as Sextus Empiricus have developed practices of argumentative inquiry that are meant to expose internal contradictions within a given position. As a result, the dispute becomes undecidable and one has to suspend

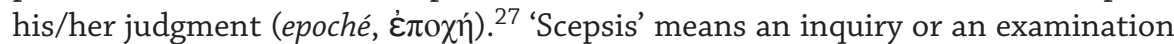
guided by reason and in search for truth, however in vain. In the interim that the university offers interruptions have to be built in that temporarily halt the creation of knowledge. Learning also involves the experience that one does not know or does not know enough. In ancient skepticism, the suspension of judgment served to attain a peaceful state of mind (ataraxia, $\alpha \tau \alpha \rho \alpha \xi i \alpha)$ so that one no longer worries about truth and falsity anymore. In my view, the ultimate goal of our questioning is not tranquillity of mind but, on the contrary, an increased awareness that knowledge is always a temporary and fallible construction and that it

25 For that reason Weber (1989, p. 25-26) argues that ends have to be established in the 'marketplace of life', whereas science should only concern itself with the means in order to achieve these ends. In his Pure Theory of Law, Kelsen (1992, p. 15-19) also bans normative questions about the law's legitimacy from the forum of science. I would not go that far, though I agree with both scholars that value judgments can never be justified scientifically. If someone wants to evaluate the law and make suggestions to amend it, it may at least be required that $\mathrm{s} / \mathrm{he}$ is transparent about the values at stake.

26 For an introduction to the Socratic method in legal education, see Areeda (1996). Kennedy (2004b, p. 126) clearly dismisses this method, when he encourages students to refuse 'to go along with the ritual of the socratic method'.

27 Burnyeat (1983) gives an insightful description of the skeptical practice of inquiry. In a next article that I am writing together with Bald de Vries, I will show how my notion of 'skeptical legal education' relates to both the ancient and modern understanding of skepticism. 
has - as soon as it is accepted and becomes naturalized and fixed as truth - a huge impact on our convictions and actions. In our modern age knowledge acquired at universities is used more and more to intervene in society. ${ }^{28}$ A reflection on the way knowledge shapes society, for better or worse, should therefore be part of every education. Students have to learn that knowledge, in its application, can be misinterpreted, distorted, even abused and may have serious negative side effects. $^{29}$

Finally, on the institutional level, the faculty management has to provide for a mixture of teachers with different political, cultural, and religious backgrounds. If they are exposed to a variety of opinions, students will soon discover that truth in science is always a matter of debate. As Oakeshott argues, education is an introduction to a shared inheritance. However, the inheritance that is handed over from one generation to the other is not a fixed entity, but is changed in every transmission. ${ }^{30}$ Every teacher will give his/her own version of the canonical texts, depending on the theoretical perspective and worldview s/he has adopted. Not one dominant voice should be heard, but a plurality of voices. This plurality of voices will inevitably be a limited plurality, because not everyone will be allowed to speak. In the selection of teachers not only academic requirements are applied (teachers have to have the right qualifications), but also norms of decency (teachers have to meet some standard of good behaviour and political correctness). ${ }^{31}$ Kennedy is undoubtedly right that the mainstream in law schools is quite moderate. Generally speaking, law teachers are conservative in the sense that they want to protect what they deem to be valuable in the law as it is. They tend to resist radical change because they believe - for good reasons - that a legal system can only function properly if the law is more or less stable and predictable. However, within this mainstream many different (liberal, republican, conservative, communitarian, feminist and other) positions can be discerned and, if one listens carefully, one may even hear some radical and 'critical' tones. In order to set the stage for a (by necessity limited) plurality of voices, the curriculum should not only consist of courses where the 'black letter law' is taught, but also of courses in which the law's efficacy and legitimacy and its historical development can be discussed on a more principled level. This is the field of the so-called 'meta-juridical' courses, such as legal sociology, legal philosophy and legal history. Although they are doomed to remain in the periphery, as Kennedy rightly notices, they are central for critical reflection on the law as it is and ought to be according to mainstream law teachers.

According to Giddens (1991, p. 123), the era of late modernity is characterized by 'regular shifts in knowledge-claims as mediated by expert systems'.

29 Weber (1989, p. 22) puts it as follows: 'Anybody who is a reasonable teacher has as his first duty to teach his students to acknowledge "inconvenient" facts, I mean facts which are inconvenient for their party opinion.'

30 This follows from Gadamer's characterization of understanding as application (Gadamer 2006, p. 305-308).

31 Universities will, for instance, not be inclined to give voice to teachers with overtly fascist sympathies. 
Skeptical legal education does not mean that law teachers have to reject the legal system at hand, in part or on the whole (nor do they have to embrace it wholeheartedly). It means that they are asked to present their knowledge claims and value judgments for what they are: fallible opinions which are debatable and have to be debated within the community of both teachers and learners. This will improve the students' faculty of judgment and make them more critical towards people who want to impose their worldview on them. So it appears that learning, after all, does have an indirect instrumental value, namely to make students skeptical towards any attempt to instrumentalize knowledge for dubious purposes and to apply it in an uncritical manner.

\section{References}

\section{Areeda 1996}

Phillip E. Areeda, 'The Socratic Method', Harvard Law Review 1996, p. 911-922.

\section{Aristotle 2011}

Aristotle, Nicomachean Ethics (a new Translation by Robert C. Bartlett and Susan D. Collins), Chicago: University of Chicago Press 2011.

\section{Burnyeat 1983}

M.F. Burnyeat, 'Can the Skeptic Live His Skepticism?', in: Myles Burnyeat (ed.), The Skeptical Tradition, Berkeley: University of California Press 1983, p. 117-148.

\section{Carrington 2004}

Paul Carrington, 'Reproducing the Right Sort of Hierarchy', in: Duncan Kennedy, Legal Education and the Reproduction of Hierarchy. A Polemic against the System, New York: New York University Press 2004, p. 145-153.

\section{Corrias 2011}

Luigi Corrias, The Passivity of Law. Competence and Constitution in The European Court of Justice, Dordrecht: Springer 2011.

\section{Franco 1990}

Paul Franco, The Political Philosophy of Michael Oakeshott, New Haven, CT: Yale University Press 1990.

\section{Fuller 2001}

Timothy Fuller, 'Introduction. A Philosophical Understanding of Education', in: Michael Oakeshott, The Voice of Liberal Learning, Indianapolis: Liberty Fund 2001, p. $x v-x x x v$.

Gadamer 2006

Hans-Georg Gadamer, Truth and Method. Second, revised edition. Translation revised by Joel Weinsheimer \& Donald G. Marshall, London: Continuum 2006.

\section{Giddens 1991}

Anthony Giddens, Modernity and Self-Identity. Self and Society in the Late Modern Age, Cambridge: Polity Press 1991.

\section{Kelsen 1992}

Hand Kelsen, Introduction to the Problems of Legal Theory. A Translation of the First Edition of the Reine Rechtslehre or Pure Theory of Law (originally published in 1934), Oxford: Clarendon Press 1992.

\section{Kennedy 1986}

Duncan Kennedy, 'Liberal Values in Legal Education', Nova Law Journal 1986, p. 603-617. 


\section{Kennedy 1990}

Duncan Kennedy, 'The Liberal Administrative Style', Syracuse Law Review 1990, p. 801-812.

\section{Kennedy 1994}

Duncan Kennedy, 'Politicizing the Classroom', Review of Law and Women's Studies 1994-4, p. 81-88.

\section{Kennedy 2004a}

Duncan Kennedy, 'Introduction', in: Duncan Kennedy, Legal Education and the Reproduction of Hierarchy. A Polemic against the System, New York: New York University Press 2004, p. 1-7.

\section{Kennedy 2004b}

Duncan Kennedy, 'Legal Education and the Reproduction of Hierarchy', in: Duncan Kennedy, Legal Education and the Reproduction of Hierarchy. A Polemic against the System, New York: New York University Press 2004, p. 9-144.

\section{Kennedy 2004c}

Duncan Kennedy, 'Afterword', in: Duncan Kennedy, Legal Education and the Reproduction of Hierarchy. A Polemic against the System, New York: New York University Press 2004, p. 202-222.

\section{Van Klink 2011}

Bart van Klink, 'De kunst van het converseren. Over de rol van vaardigheden in Michael Oakeshotts opvatting van liberal learning,' in: C.G. Breedveld-de Voogd (ed.), Signora Senatrice. Over recht, onderwijs en politiek. Opstellen aangeboden aan Ankie Broekers-Knol, Den Haag: Boom Juridische uitgevers 2011, p. 217-225.

\section{Van Klink 2012}

Bart van Klink, 'Waarom zouden we ons aan de wet houden? Een pleidooi voor versterking van het staatsgezag', in: Thijs Jansen, Gabriël van den Brink \& René Kneyber (eds.), Gezagsdragers. De publieke zaak op zoek naar haar verdedigers, Amsterdam: Boom 2012.

\section{Van Klink \& Lembcke 2013}

Bart van Klink Oliver W. Lembcke, 'What Rules the Rule of Law? A Comparison between Michael Oakeshott and Hans Kelsen', in: Michael Henkel \& Oliver W. Lembcke (eds.), Praxis und Politik. Michael Oakeshott im Dialog, Tübingen: Mohr Siebeck 2013 (forthcoming).

\section{Kronman 2007}

Anthony T. Kronman, Education's End. Why Our Colleges Have Given Up on the Meaning of Life, New Haven, CT: Yale University Press 2007.

\section{Lembcke 2011}

Oliver Lembcke, 'Law and Political Theory. The Other Side of the Story', in: Bart van Klink \& Sanne Taekema (eds.), Law and Method, Tübingen: Mohr Siebeck 2011, p. 153-174.

\section{Oakeshott 1975}

Michael Oakeshott, On Human Conduct. Oxford: Clarendon Press 1975.

\section{Oakeshott 1991a}

Michael Oakeshott, 'Political Education', in: Michael Oakeshott, Rationalism in Politics and Other Essays, Indianapolis, IN: Liberty Fund 1991, p. 43-69.

\section{Oakeshott 1991b}

Michael Oakeshott, 'On Being Conservative', in: Michael Oakeshott, Rationalism in Politics and Other Essays, Indianapolis, IN: Liberty Fund 1991, p. 407-437. 


\section{Oakeshott 1999}

Michael Oakeshott, 'The Rule of Law', in: Michael Oakeshott, On History and Other Essays, Indianapolis, IN: Liberty Fund 1999, p. 129-178.

\section{Oakeshott 2001}

Michael Oakeshott, The Voice of Liberal Learning, Indianapolis, IN: Liberty Fund 2001.

\section{Ramsden 2003}

Paul Ramsden, Learning to Teach in Higher Education (2nd ed.), Oxon: RoutledgeFalmer 2003.

Raz 1979

Joseph Raz, The Authority of Law. Essays on Law and Morality, Oxford: Clarendon Press 1979.

\section{Shain 2000}

Ralph Shain, 'Legal Education and Hierarchy. A Reply to Duncan Kennedy', The Journal of Ideology, an electronic journal at: <www.lsus.edu/journalofideology>, Vol. 23, Nrs. 1-2, 2000, p. 1-31.

\section{Weber 1989}

Max Weber, 'Science as a Vocation' (translated by Michael John), in: Peter Lassman, Irving Velody \& Herminio Martins (eds.), Max Weber's Science as a Vocation, London: Unwin Hyman 1989.

\section{Weber 1994}

Max Weber, 'The Profession and Vocation of Politics', in: Peter Lassman \& Ronald Speirs (eds.), Weber: Political Writings, Cambridge: Cambridge University Press 1994, p. 309-369. 